\title{
Sastra dan Masyarakat: Fenomena Ambyar pada Lirik Lagu Didi Kempot
}

\author{
Ferdian Achsani \\ MTs Al Mujahidin Surakarta \\ dwikurniawan219@gmail.com
}

\begin{abstract}
Didi Kempot or the father of a national heartbreak may already be familiar to the ears of the people of Indonesia, even abroad, especially Suriname and Belanda. The emergence of Didi Kempot revived music campursari which had long been vacuum and was once again accepted by the public from all walks of life. This distinctive mixed singer with mellow nuances is now being loved by the public, especially young people. This study aims to describe the form of ambyar phenomenon in the lyrics of the song Didi Kempot with the public. This research is a qualitative descriptive type, using content analysis as a data analysis technique. Data collection is carried out by conducting documentation studies. Data validity test is done by using triangulation of research results showing that Didi Kempot's lyrics represent the feelings of ambyar young people in having a love relationship such as being cheated, broken promises, disappointed, and harbored a longing. The background of this ambyar phenomenon is due to a lack of concern or commitment in establishing relationships, economic factors, establishing long-distance relationships, remembering memories with ex, etc.

Keywords: song lyrics, ambyar, literature and society.
\end{abstract}

\begin{abstract}
Abstrak
Didi Kempot atau bapak patah hati nasional mungkin sudah tidak asing lagi di telinga masyarakat Indonesia, bahkan luar negeri khususnya Suriname dan Belanda. Kemunculan Didi Kempot kembali membangkitkan music campursari yang sempat lama vakum dan kembali diterima oleh masyarakat dari semua kalangan. Penyanyi campursari yang khas dengan lagu-lagu bernuansa mellow ini kini tengah digandrungi oleh masyarakat, khususnya anak muda. Penelitian ini bertujuan untuk mendeskripsikan bentuk fenomena ambyar pada lirik lagu Didi Kempot dengan masyarakat. Penelitian ini termasuk jenis deskriptif kualitatif, dengan menggunakan metode analisis isi sebagai teknik analisis data. Pengumpulan data dilakukan dengan melakukan studi dokumentasi. Uji keabsahan data dilakukan dengan menggunakan triangulasi sumber hasil penelitian menunjukkan bahwa lirik lagu Didi Kempot mewakili perasaan ambyar kawula muda dalam menjalin hubungan asmara seperti diselingkuhi, diingkari janji, kecewa, dan memendam rasa rindu. Hal yang melatarbelakangi fenomena ambyar ini dikarenakan kurangnya rasa perhatian atau komitmen dalam menjalin hubungan, factor ekonomi, menjalin hubungan jarak jauh, teringat kenagan-kenangan bersama mantan, dll.
\end{abstract}

Kata kunci: lirik lagu, ambyar, sastra dan masyarakat.

\section{PENDAHULUAN}

Musik campursari merupakan salah satu musik daerah yang melegenda dan merakyat. Tak hanya itu musik campursari merupakan salah satu musik yang menjadi ciri khas atau karakteristik budaya bagi masyarakat, khususnya bagi wilayah Jawa Tengah dan DIY. Berdirinya musik ini dipelopori oleh aktivitas musik campursari RRI Semarang pada tahun 1953. Perjuangan untuk memperkenalkan music ini kepada masyarakat tidaklah mudah. Hal 
ini dilakukan melalui rekaman yang dilakukan sampai lima kali yang digunakan sebagai cara untuk menyebarluaskan musik campursari kepada masyarakat (Wiyoso, 2007), meskipun pada akhirnya tetap tidak berhasil. Penyebabnya, masyarakat lebih tergiur oleh langgam sekaligus Gending kreasi Ki Narto Sabdo. Tetapi pada tahun 90-an, musik campursari mengalami perombakan dengan masuknya keyboard dan gitar ekktrik yang dipelopori oleh Manthos. Hal ini menjadikan akulturasi budaya antara tradisional dengan modern, yang mampu memikat hati masyarakat hingga musik ini pernah mengalami masa keemasan pada tahun 2000-an, dan terciptanya musik dangdut.

Setelah beberapa lama vakum, kini musik campursari kembali heboh dengan fenomena anak muda (millennial) yang mengidolakan Didi Kempot. Didi Kempot merupakan salah satu musisi yang sudah lama berkecimpung dalam dunia musik campursari. Kemunculannya di jagad hiburan sebenarnya sudah lama dan sudah hampir beberapa album diproduksi olehnya sejak 1999 silam. Tetapi masyarakat baru memberikan julukan bapak patah hati, setelah lagulagu ciptaannya mewakili perasaan anak muda yang merasa tersakiti, gagal menjalin hubungan asmara, dikecewakan dan sebagainya yang berhubungan dengan asmara. Lagu-lagu yang dibawakan oleh Didi Kempot ini seakan mewakili perasaan para fans yang menyebut namanya sad Boys, sad girls ataupun sobat ambyar ini.

Lagu-lagu yang dibawakannya selalu bertema patah hati dengan tujuan agar lagu tersebut tetap bertahan di pasaran dan dapat dinikmati oleh seluruh kalangan. Harapan Didi tersebut ternyata membuahkan hasil yang dapat dilihat bahwa lagu-lagu yang diciptakannya pada tahun 90-an ini kembali hidup di tengah arus modernisasi dan globalisasi. Hal yang menjadikan lagu tersebut kembali hidup karena lirik-lirik yang dituliskannya mewakili isi hati setiap orang. Didi sendiri mengaku senang karena masyarakat sudah kembali menerima musik campursari bahkan dapat dikenal oleh seluruh masyarakat Indonesia. Merebaknya fenomena Didi Kempot ini pun mendapat julukan The Godfather Of Broken Heart. Semua masyarakat dari petani hingga berdasi sudah kenal dan akrab dengan penyanyi campur sari yang kondang dan hits tersebut. Bahkan lagu yang paling enak didengarkan ketika siang hari sambil leyehleyeh yang sering diputar di radio local ini, kini semakin enak didengar kapanpun dan di manapun. Dengan demikian music campursari yang sempat terkesan kampungan kini menjadi salah satu music fenomenal yang merakyat dan tidak mengenal status social.

Hampir lebih dari 131 lagu yang dibawakan oleh Didi Kempot ini memang mewakili perasaan seseorang yang sedang dirundung kasmaran hingga gagal dalam bercinta. Setiap lirik lagunya mampu membuat setiap penonton bergoyang bahkan juga sanggup membuat penonton berderai air mata. Tidak sedikit dari penonton yang menangis ketika meyaksikkkan dan ikut bernyanyi ketika menghadiri konser Didi Kempot. Misalnya lagu layang kangen yang menggambarkan perasaan kangen seseorang terhadap kekasihnya. Lagu yang berisikan perasaan rindu ini mendapat apresiasi dari masyarakat karena menggambarkan perasaan mereka yang sedang menjalin hubungan jarak jauh (LDR). Dari layang kangen, Didi juga membawakan lagu kalung emas yang sempat membuat salah seorang penonton mengeluarkan umpatan "Bajingan" dalam acara ngobam pada Juli lalu. Lagu yang menceritakan perasaan 
sedih, kecewa karena rasa cinta kekasihnya sudah mulai luntur ini juga menggambarkan perasaan kawula muda saat ini. Hal tersebutlah yang semakin membuat lord Didi semakin diterima oleh masyarakat, karena selain lagu-lagu yang dibawakannya konsisten bertema patah hati, dengan penggunaan bahasa Jawa yang sederhana dan mudah diterima khayalak masyarakat. Bahkan tak hanya masyarakat Jawa, ketika menggelar konser di Jakarta dia cukup terkejut ketika mengetahui bahwa masyarakat hafal akan lagu-lagu berbahasa Jawa tersebut (Antara, 2019).

Dilansir dari mojok.com ketika diwawancarai, Didi Kempot sempat mengutarakan bahwa penciptaan lagu-lagu nya ditulis berdasarkan peristiwa patah hati yang sukses membuat seluruh laki-laki menangis (Anonim, 2019). Bagi Didi Kempot, patah hati bukan saatnyan untuk bersedih tetapi melalui patah hati harus digendangi, dijogeti dan bisa digunakan untuk memotivasi diri agar lebih baik. Dari hal tersebutlah penyanyi Didi Kempot identik dengan lagu-lagu yang selalu bertema patah hati. (Dwisantoso, 2019) juga menambahkan fenomena tenarnya penyanyi Didi Kempot ini dikarenakan rasa bosan masyarakat terutama kawula muda dalam mendengarkan lagu-lagu bernuansa pop. Perkembangan industri musik di tanah air sendiri memang sering mengalami perubahan. Jika dahulu masyarakat sempat dibuat gempar dengan kehadiran band pop seperti Peterpan yang berganti nama menjadi Noah, Geisha, Kotak, kemudian berubah menjadi selera musik dance dengan kehadiran boy band \& girl band seperti Smash, Cherrybelle, 7 Icon, Blink dan puncaknya pada akhir 2016 masyarakat dikenalkan dengan lagu-lagu mellow-dangdut yang dinyanyikan penyanyi Pantura seperti Via Vallen, Nella kharisma, Tasya rosmala, hingga Abah Lala, Denny Caknan, dll.

Dilihat dari segi bahasa, adanya lagu-lagu Didi Kempot yang mulai digandrungi kawula muda ini, dapat dijadikan sebagai sarana untuk mempertahankan bahasa daerah, yang mana bahasa daerah khususnya bahasa jawa saat ini sudah mulai luntur (Suharyo, 2018). Mengingat saat ini bahasa daerah mengalami kepunahan, sehingga dapat dijadikan sebagai strategi untuk mempertahankan bahasa Jawa. Tak hanya melestarikan bahasa daerah, penggunaan lirik lagu berbahasa jawa ini diharapkan dapat mempromosikan bahasa jawa agar lebih mendunia (Yunianti, 2019). Dari segi sastra, lirik lagu ini dapat digunakan untuk mencerminkan kehidupan masyarakat saat ini. Pasalnya sastra dan masyarakat tidak dapat dipisahkan. Seperti yang telah disampaikan sebelumnya bahwa Penciptaan lagu-lagu campursari karya Didi Kempot yang melegenda ini merupakan cerminan kehidupan masyarakat. Fenomena ambyar yang terjadi di masyarakat, menjadikan Didi Kempot untuk menciptakan lagu-lagu yang bernuansa demikian.

Dalam menuliskan sebuah karya sastra, pengarang tidak sembarangan dalam menuliskan fenomena yang terjadi di masyarakat. Pengarang juga perlu untuk melakukan riset atau pengamatan layaknya penelitian, agar karya sastra yang dituliskannya dapat mengena dan diterima baik oleh masyarakat. Mengingat bahwa suatu karya sastra diciptakan karena dipiicu oleh kehidupan social (Rizaldy, 2016). Pengarang sebagai anggota masyarakat memanfaatkan fenomena yang terjadi di masyarakat berdasarkan hasil penelitian yang telah dilakukannya sebagai sumber kekayaan dalam karya sastra yang ditulis. Dengan memanfaatkan fenomena 
yang terjadi di masyarakat tersebut penyebaran aspek budaya masyarakat menjadi lebih mudah diterima dan dipahami. Karya sastra juga dapat lebih mudah untuk dihayati dan dirasakan, sehingga karya sastra juga dapat dijadikan sebagai renungan dalam kehidupan sehari-hari (Wahyuni, 2018). Bahkan karya sastra tersebut kembali dimanfaatkan oleh masyarakat sebagai fungsi estetik dan etika bagi masyarakat. Misalnya dalam cerpen Cimuntu Lansie" Karya Wisran Hadi, yang mengungkapkan nilai-nilai luhur budaya Mingkabau (Suhardi, 2018). Nilai-nilai luhur seperti nilai religius, kejujuran, toleransi, disiplin, demokrasi, komunikatif, cinta damai, sosial, dan nilai tanggung jawab merupakan cerminan masyarakat Minangkabu. Dari cerpen tersebut penyebaran aspek budaya masyarakat menjadi lebih mudah dan dapat diterima.

Penggambaran lirik lagu Didi Kempot sebagai cerminan masyarakat dapat dilihat dari komentar-komentar nitizen yang berada di setiap unggahan video. Salah satu yang tampak mencolok dari komentar-komentar yang terdapat pada lagu-lagu campurasari maupun dangdut yang bernuansa galau adalah fenomena sobat ambyar. Hal ini sangat jelas bagaimana netizien mencurahkan perasaan galau atau ambyar mereka dalam sebuah komentar. Sobat ambyar yang mencerminkan kesedihan seseorang karena berhubungan dengan kekasihnya, juga termasuk dalam realitas social masyrakat (Marlina, 2018).

Saat ini komentar sudah seperti tempat bagi masyarakat untuk mencurahkan segala macam persoalan yang dihadapinya. Biasanya, orang akan membuat caption atau komentar unik dan menarik yang bertujuan untuk mempengaruhi masyarakat, mencurahkan isi hati, menyindir dll. Dengan demikian komentar juga dapat dijadikan sebagai sarana untuk menyebarluaskan informasi kepada masyarakat. Melalui kolom dengan karakter terbatas, nitizen selalu memanfaatkannya untuk mencurahkan segala isi hati. Kolom komentar sudah selayaknya buku diary bagi nitizen. Maka tak heran bahwa kolom komentar di jejaring sosial YouTube juga berisikan curahan hati yang dialami oleh nitizen. Di era modern ini kolom komentar dapat dijadikan sebagai sarana komunikasi antar masyarakat.

Penelitian ini bertujuan untuk mendeskripsikan bagaimana fenomena sobat ambyar dalam lirik lagu campursari Didi Kempot. Penelitian yang relevan dengan penelitian ini dilakukan oleh (Rahma \& Wijaya, 2018) dalam mengkaji puisi Wiji Thukul. Hasil penelitian tersebut menyimpulkan bahwa puisi Wiji Thukul, mencerminkan kehidupan masyarakat di era pengarang, yaitu era pemerintahan Orde Baru yang menceritakan penindasan bagi kalangan bawah, termasuk penyair (Wiji Thukul). Hal ini dapat dilihat dari lirik-lirik pada puisi Wiji Thukul, yang mana secara keseluruhan menceritakan kehidupan pada era pemerintahan Orde Baru. Persamaan dengan penelitian tersebut adalah mengkaji penggambaran masyarakat dalam karya sastra, puisi. Perbedaannya terdapat pada objek yang digunakan dalam penelitian, yaitu antara puisi kasrya Wiji Thukul dan lirik lagu Didi Kempot.

Penelitian ini termasuk dalam deskriptif kualitatif. Hal ini dikarenakan penelitian kualitatif merupakan bentuk penelitain yang berusaha menjabarkan fenomena-fenomena social yang ditemui oleh peneliti melalui rangkaian bahasa dan kata-kata. Pengolahan data yang dilakukan dalam mengkaji lirik lagu Didi Kempot ini yaitu menguraikan kata-kata dan bahasa. 
Dengan demikian studi dokumentasi dilakukan sebagai metode dalam pengumpulan data. Penelitian ini menggunakan metode analisis isi, yaitu dengan memberikan pemaknaan terhadap lagu-lagu karya Didi Kempot. Hal ini sesuai dengan hakikat analisis isi, yang mana penelitian ini memaparkan isi dengan memperhatikan pada makna kontekstual. Pemberian makna kontekstual pada lirik lagu Didi Kempot ini dikaitkan dengan komentar-komentar nitizen di jejaring sosial, yang mencerminkan dari isi lagu Didi Kempot, meskipun komentar yang diambil tidak secara langsung diambil dari komentar dari video Didi Kempot tetapi juga beberapa komentar dari video yang mewakili isi lagu Didi Kempot. Dari komentar nitizen tersebut dapat digunakan sebagai keabhsahan data, dengan memanfaatkan triangulasi sumber.

\section{PEMBAHASAN}

\section{Ingkar janji}

Dek opo salah awakku iki

Kowe nganti tego mblenjani janji

Opo mergo kahanan uripku iki

Mlarat bondo seje karo uripmu

Aku nelongso mergo ke bacut tresno

Ora ngiro saikine cidro
Apa ada salah diriku ini

Kau sampai tega mengingkari janji

Apa karena keadaan hidupku iniMiskin harta

benda dibanding hidupmu

Aku merana karena terlanjur cinta

Tak mengira sekarang mengingkarinya

Lirik lagu Cidro di atas menggambarkan bagaimana perasaan rasa cinta yang dimiliki oleh seorang yang tega dikhianati oleh orang yang ia cintai. Dalam lirik lagu tersebut penyair memanfaatkan jenis pertanyaan spesifik untuk membutuhkan jawaban yang pasti dari kekasihnya, mengapa tega mengingkari janji. Penyair tidak pernah menyangka sebelumnya bahwa perempuan yang dicintainya akan tega menyakitinya. Hal ini hanya disebabkan karena penyair yang tidak memiliki harta yang berlimpah sehingga cintanya tega dikhianati oleh kekasihnya. Dengan demikian lirik lagu tersebut dapat menggambarkan perasaan ambyar yang mana merasakan perasaan dibohongi atau diingkari janji. Lirik lagu tersebut merupakan penggambaran perasaan yang pernah dialami sendiri oleh Didi Kempot. Didi Kempot yang dulunya seorang pengamen jalanan, pernah mencintai seorang perempuan. Namun sayangnya rasa cintanya tidak pernah direstui oleh kedua orang tua sang perempuan. Hal ini dikarenakan kehidupan Didi Kempot yang dulunya seorang pengamen, sehingga mereka tidak rela jika anaknya harus menikah dengan Didi.

Paribasan awak urip kari balung Lilo tak lakoni

Jebule janjimu jebule sumpahmu Ra biso digugu
Ibarat badan hidup tinggal tulang

Rela aku jalani

Ternyata janji dan sumpahmu

Tak bisa dipercaya 
Penggalan lirik lagu suket teki ini juga menceritakan kisah perasaan ambyar yang dikhanati oleh kekasihnya karena dibohongi atau diingkari janji. Hal ini dapat dilihat pada larik tiga dan empat, yang mana pada bait tersebut disebutkan bahwa janji dan sumpah yang pernah diucapkan oleh kekasihnya tersebut tidak pernah terbukti. Bisa dikatakan bahwa janji dan sumpah tersebut hanya omong kosong yang hanya mudah diucapkan, berat dilakukan. Padahal jika dilihat pada larik sebelumnya, diceritakan bahwa kekasihnya tersebut rela berkorban walaupun sampai tubuhnya habis hanya tersisa tulang. Hal ini merupakan bentuk pengorbanan untuk membuktikan besar rasa cinta kepada kekasihnya tersebut.

Janji Lungo Mung Sedelo
Jare Sewulan Ra Ono
Pamitmu Naliko Semono
Ning Stasiun Balapan Solo

\section{Janji pergi hanya sebentar \\ Sampai sebulan tidak ada \\ Pamitmu waktu itu \\ Di stasiun balapan solo}

Sama dengan lagu Suket Teki dan Cidro, pada lirik lagu Stasiun Balapan ini juga menceritakan kisah ambyar perjalanan seorang kekasih yang diingkari janjinya. Pada penggalan lirik tersebut diceritakan bahwa penyair mengingat pesan-pesan kekasihnya bahwa ia tidak akan pergi lama tidak akan pergi sampai satu bulan. Namun sayangnya setelah ditunggu hingga satu bulan berakhir, sang kekasih yang diharapkan ini tak juga kembali untuk menepati janjinya. Dari lirik tersebut sehingga dapat dikatakan bahwa menggambarkan seorang laki-laki yang ditinggal pergi kekasihnya dan diingkari janjinya. Pemanfaatan Stasiun Balapan Solo dijadikan sebagai latar tempat bagi penyair untuk menceritakan kronologi kejadian yang pernah dialaminya.

Dari beberapa lirik lagu di atas, dapat dikatakan bahwa fenomena ambyar yang tergambar dalam lirik lagu Didi Kempot ini salah satunya adalah karena diingkari janji oleh kekasihnya. Hal ini biasa terjadi karena biasanya, sepasang kekasih apabila sudah menjalin hubungan pasti mereka akan melontarkan janji-janji yang bertujuan untuk meyakinkan perasaan pasangannya. Misalnya dalam lirik lagu di atas digambarkan bahwa janji yang dibuat adalah sang kekasih tidak akan pergi lama dan pasti akan kembali. Tetapi ternyata janji tersebut tidak dapat dipercaya, malah justru dikhianati. Hal ini biasanya terjadi karena sang kekasih mungkin sudah menemukan pengganti atau orang lain yang dirasa mampu memberikan segalanya, misalnya dari segi materi. Hal tersebut dapat menjadi salah satu penyebab utama ingkar janji pada pasangan kekasih.

\section{Menahan rindu}

Aku nangis, aku kangen

Janjine biyen kowe seneng

Neng Nickerie tak enteni

Gek muliho neng kene aku ngenteni
Aku nangis aku kangen

Janjinya dulu engkau senang

Ke Nickerie engkau ku tunggu

Segerlah pulang di sini ku menanti 
Lirik lagu Didi Kempot berjudul Kangen yang berduet dengan Dori ini merupakan gambaran kisah pilu Dori yang ditinggal pergi oleh kekasihnya. Hal ini diungkapkan sendiri oleh Didi Kempot ketika membawakan lagu tersebut pada konser yang digelar di Mangkunegaran hingga membuat pemain gendang tersebut banjir air mata. Pada penggalan lirik lagu tersebut menggambarkan perasaan kangen, rindu seorang laki-laki pada perempuan yang dicintainya. Perasaan rindu tersebut disebabkan karena besarnya rasa cinta yang dimiliki oleh sang lakilaki tetapi justru perempuan yang dicintainya tak menghiraukan perasaan sang lelaki. Meskipun sang perempuan memilih pergi ke Nickerie, dan sudah tidak lagi memberikan kabar pada sang lelaki, namun sang lelaki tetap menunggu pujaan hatinya tersebut pulang, karena besarnya rasa cinta sang lelaki pada perempuan pujaannya tersebut. Perasaan kangen yang dialami oleh Dori ini menjadi bentuk fenomena ambyar.

Ora maido sopo wong sing ora kangen

Adoh bojo arep turu angel

merem

Ora maido sopo wong sing ora trenyuh

Ora kepethuk sak wetoro pengen weruh

Percoyo aku, kuatno atimu

Cah ayu, entenono tekaku percayalah siapa yang tidak kangen

jauh dengan kekasih ingin tidur sulit

memejamkan mata

percayalah siapa yang tidak tersentuh

tidak bertemu sejenak ingin tahu

percaya aku, kuatkan hatimu

gadis cantik tunggulah kedatanganku

Lirik lagu ambyar yang menceritakan kerinduan seseorang pada kekasihnya juga tergambar pada penggalan lirik lagu di atas. Dalam lirik lagu tersebut menggambarkan perasaan seorang laki-laki yang begitu merindukan kekasihnya karena terbentur jarak yang jauh. Lirik lagu tersebut mewakili perasaan bagi sepasang kekasih yang menjalin hubungan jarak jauh (LDR). Pada lirik lagu tersebut menggambarkan bagaimana perasaan seorang kekasih yang sudah lama tidak bertemu dengan kekasihnya dan begitu sangat merindukan kekasihnya. Rasa rindu pada kekasihnya ini pun berdampak pada dirinya hingga sulit dan tidak bisa memejamkan mata. Untuk membunuh rasa rindu tersebut, sang kekasih berpesan agar saling menguatkan hati dan percaya satu sama lain. Sang lelaki juga berpesan pada kekasihnya tersebut untuk menanti kehadirannya karena ia pasti akan kembali dan pulang sehingga bisa bertemu dan melepas rindu.

Sworo angin

Angin sing ngreridu ati

Ngelingake sliramu sing tak tresnani

Pengen nangis

Ngetokke eluh neng pipi

Suwe ra weruh

Senajan mung ono ngimpi

Ngalemo
Suara angin

Angin yang menggerakkan hati

Mengingatkan tentangmu yang ku cintai

Ingin ku menangis

Meneteskan air mata di pipi

Lama tak berjumpa

Meskipun hanya di mimpi

Bersandarlah 
Ngalem neng dadaku

Tambanono roso kangen neng atiku

Ngalemo

Ngalemo neng aku

Ben ra adem kesiram udaning dalu Banyu langit
Bersandarlah di dadaku

Obatilah rasa rindu di hatiku

Bersandarlah

Bersandar kepadaku

Agar tak terasa dingin dengan hujan di malam hari

Air langit

Perasaan rindu hingga membuat ambyar seseorang juga tergambar dari lirik lagu di atas. Dalam lirik lagu Banyu Langit ini digambarkan perasaan rindu penyair kepada seseorang yang dicintainya, namun rasa cintanya tak pernah terbalaskan. Kepergian sang kekasih yang dirasa sudah terlalu lama membuat rindu di hati penyair dan ingin untuk segera bertemu. Namun pertemuan yang diinginkannya tidak pernah terwujudkan meskipun hanya bertemu dalam mimpi. Dari lirik lagu tersebut penyair menuliskan agar sang kekasih bermesraan dengan bersandar di dada penyair untuk membunuh rasa rindu setelah sekian lama tak bertemu. Dengan bersandar di dada penyair diharapkan sang kekasih tidak akan merasa dingin karena tersiram air hujan di malam hari.

Perasaan ambyar juga dapat terjadi ketika seseorang sedang menahan rindu, sedangkan orang yang dirindukan tidak pernah menghiraukan rasa rindunya. Hal ini tergambar jelas dari liriklirik lagu yang telah dijabarkan di atas. Pada lirik lagu Kangen yang dinyanyikan oleh Didi Kempot dengan menggandeng pemain gendangnya tersebut, menggambarkan bagaimana perasaan rindu yang dialami oleh Dori tetapi orang yang dirindukannya malah justru pergi dan tidak ada kabar. Tetapi rasa rindu juga dapat terjadi Ketika seseorang tengah merasakan hubungan jarak jauh dengan kekasihnya (LDR). Jarak dan waktu yang menjadi penghalang hubungan untuk bertemu menimbulkan rasa ambyar sehingga bertemu menjadi obat ampuh untuk mengatasinya. Dengan demikian perasaan ambyar ketika merindukan seseorang tidak hanya terjadi ketika rasa rindu seseorang dihiraukan tetapi juga ketika sepasang kekasih sudah lama tak saling jumpa dan sapa.

\section{Mengingat Kenangan}

Ning Stasiun Balapan

Kuto Solo Sing Dadi Kenangan

Kowe Karo Aku

Naliko Ngeterke Lungamu
Di stasiun balapan

Kota solo yang jadi kenangan

Kamu dengan aku

Ketika mengantarkan pergimu

Statiun Balapan yang berada di kota Solo menjadi salah satu tempat fenomenal bagi Didi Kempot. Di sana merupakan tempat yang menyimpan sejuta kenangan ketika mengantarkan kepergian kekasihnya. Hal ini jelas tergambar pada larik tersebut yang mana penyair menjelaskan bahwa Stasiun Balapan menjadi kenangan antara ia dan kekasihnya ketika 
mengantarkan kepergiannya. Fenomena ambyar yang tertangkap dari lirik lagu tersebut yaitu mengingat kenangan. Kenangan terakhir yang pernah dialami bersama sang kekasih di Stasiun Balapan membuat penyair kecewa, sehingga membuat penyair ambyar. Kerinduan ini terjadi ketika penyair mengingat janji bahwa kekasihnya tidak akan pergi hingga sebulan, tetapi sang kekasih justru malah mengingkarinya.

$\begin{array}{ll}\text { Aku Sik Kelingan Naliko Nang Pelabuhan } & \text { Ku masih ingat ketika di pelabuhan } \\ \text { Kowe Janji Lungo Ra Ono Sewulan } & \text { Kau berjanji pergi tak sampai sebula } \\ \text { Nanging Saiki } & \text { Namun sekarang } \\ \text { Wes Luwih Ing Janji } & \text { Sudah melebihi janji } \\ \text { Nyatane Kowe Ora Bali-bali } & \text { Ternyata engkau tak kunjung kembali } \\ \text { Ning Pelabuhan Tanjung Mas Kene } & \text { Di Pelabuhan Tanjung Mas ini } \\ \text { Biyen Aku Ngeterke Kowe } & \text { Dulu ku mengantar dikau } \\ \text { Ning Pelabuhan Semarang Kene } & \text { Di pelabuhan Semarang ini } \\ \text { Aku Tansah Ngenteni Kowe } & \text { Ku selalu menunggu kamu }\end{array}$

Tempat yang menjadi kenangan hingga membuat penyair ambyar selain Statsiun Balapan adalah pelabuhan Tanjung Emas. Sama persis dengan lirik lagu Stasiun Balapan, pada lirik di atas juga menggambarkan bagaimana rasanya ambyar ketika mengingat kenangan-kenangan indah bersama kekasihnya. Salah satu kenangan yang masih terngiang dan tidak dapat dilupakan adalah Ketika sang kekasih berjanji bahwa ia hanya akan pergi selama sebulan dan tidak lebih. Tetapi justru lagi-lagi sang kekasih mengkhianati janjinya, yaitu dengan pergi lebih dari satu bulan dan tidak ada kabar sehingga membuat penyair kecewa, ambyar, ketika mengingat kenangan di pelabuhan Tanjung Emas.

Birune segara kutha Pacitan, nyimpen janjimu seprene ra bisa ilang.

Birune segara kutha Pacitan, $P$ antai Klayar sing nyimpen sewu kenangan. Ouoo... birunya samudera kota pacitan menyimpan janjimu sampai sekarang tidak bisa hilang

birunya samudera kota pacitan pantai klayar sing nyimpen sewu kenangan hoouooo

Bukan hanya pelabuhan yang menjadi tempat bagi Didi Kempot yang selalu teringat akan kenangan-kenangannya bersama sang kekasih, tetapi Pantai Klayar juga menjadi salah satu tempat yang menyimpan kenangan terindahnya dengan sang kekasih. Hal ini dapat dilihat pada lirik lagu di atas. Penggunaan gaya bahasa personifikasi yang mengibaratkan pantai klayar layaknya benda hidup yang dapat menyimpan kenangan, dan gaya bahasa repetisi, melalui lirik tersebut memiliki makna yang disampaikan lebih mudah diterima oleh masyarakat. Penyair ingin menyampaikan bahwa Pantai Klayar menjadi objek wisata yang dulu pernah ia kunjungi dengan kekasihnya, dan menjadi saksi akan janji yang dibuat oleh 
kekasihnya. Dari Pantai Klayar ini penyair selalu teringat akan janji-janji yang pernah dibuat oleh kekasihnya namun pada akhirnya diingkari.

Kenangan indah yang pernah dilalui oleh sepasang kekasih dalam menjalin hubungan asmara tentu akan selalu teringat dan menjadi cerita indah. Terlebih lagi ketika sepasang kekasih harus berpisah, tentu hal tersebut akan menjadi kenangan indah dan tidak akan pernah terlupakan. Beberapa dari lirik lagu Didi Kempot ini menceritakan bagaimana fenomena ambyar terjadi ketika mengingat kenangan. Mengingat kenangan pada fenomena ambyar yang tergambar dari lirik lagu Didi Kempot ini digambarkan oleh sang penyair dengan memilih tempat-tempat khusus yang menjadi kenangan indah mereka berdua.

\section{Selingkuh}

$\begin{array}{ll}\text { Dudu klambi anyar sing nang njero } & \text { bukan baju baru yang ada di dalam } \\ \text { lemariku } & \text { lemariku } \\ \text { Nanging bojo anyar sing mbok pamerke } & \text { tapi suami baru yang kamu pamerkan } \\ \text { Ning aku } & \text { kepadaku } \\ \begin{array}{ll}\text { Dudu wangi mawar sing tak sawang nang } \\ \text { mripatku }\end{array} & \text { bukan harum mawar yang ku lihat di } \\ \text { mataku }\end{array}$

Nanging kowe lali nglarani wong koyo aku tapi kamu lupa menyakiti orang seperti aku

Memanfaatkan gaya bahasa Perbandingan, pada penggalan lirik lagu Pamer Bojo di atas menceritakan perasaan seorang laki-laki yang diselingkuhi oleh kekasihnya. Hal ini dapat dilihat dari perbandingan antara baju baru di lemari dengan kekasih baru. Pemanfaatan gaya bahasa ini memiliki maksud bahwa seorang perempuan yang sering pamer baju baru di lemari, tetapi pada lirik lagu tersebut justru malah memamerkan kekasih baru pada sang penyair. Dari gaya bahasa ini dapat dipahami bahwa lirik tersebut menceritakan seorang perempuan yang memamerkan laki-laki baru atau kekasih baru pada mantan kekasihnya. Fenomena ini menjadi bentuk ambyar bagi sang kekasih karena rasa cintanya telah dikhianati dengan kehadiran orang baru yang dipamerkan oleh mantan kekasihnya.

$\begin{array}{ll}\text { Neng dalan anyar kowe karo sopo } & \text { di jalan baru kamu dengan siapa } \\ \text { Aku ngerti dhewe neng ngarepe moto } & \text { aku tahu sendiri di depan mata } \\ \text { Neng dalan anyar kowe karo sopo } & \text { di jalan baru kamu dengan siapa } \\ \text { Neng kulon terminal kertonegoro ngawi } & \text { di sebelah barat terminal kertonegoro } \\ & \text { ngawi }\end{array}$

Penggalan lirik lagu Dalan Anyar di atas menceritakan perasaan seorang penyair yang merasa sakit hati karena diselingkuhi oleh kekasihnya. Dalam lirik tersebut digambarkan dengan kesaksian penyair yang melihat sendiri bahwa kekasihnya berduaan dengan orang lain di Dalan Anyar yang berada disebelah barat Terminal Kertonegoro, Ngawi. Dari pertanyaan penyair yang kemudian dibuat menjadi sebuah lirik lagu tersebut jelas menggambarkan bahwa lirik tersebut menggambarkan perasaan seorang laki-laki yang diselingkuhi atau diduakan rasa 
cintanya. Pertanyaan tersebut juga berisi perasaan kecewa karena kekasihnya berduaan dengan orang lain.

Selingkuh menjadi salah satu fenomena ambyar yang paling fenomenal. Sebab, fenomena ambyar terjadi ketika seseorang telah menaruh perasaan pada orang lain, teapi ternyata ia dikhianati dengan hadirnya orang ketiga. Orang ketiga ini hadir sebagai pengacau dalam hubungan sepasang kekasih. Dalam lirik lagu Didi Kempot ini, selingkuh diperlihatkan pada lirik lagu Bojo Galak, yang mana perempuan yang dicintainya memamerkan kekasih barunya yang ditunjukkan kepada mantan kekasihnya. Pada lirik lagu Dalan Anyar, selingkuh ditunjukkan dengan sikap sang kekasih yang jalan berdua dengan orang lain.

\section{Fenomena Ambyar Masyarakat \\ Selingkuh}

Selingkuh menjadi salah satu penyakit dalam menjalin sebuah hubungan. Hal ini dapat terjadi ketika salah satu orang dari sepasang kekasih berpaling dan mengkhianati cintanya dengan kekasih sebelumnya demi memilih yang baru. Fenomena selingkuh di masyarakat terjadi ketika pasangan kekasih kurangnya menaruh rasa perhatian satu sama lain dan kurangnya menerima keadaan kekasihnya seperti factor ekonomi yang rendah dan kalah cantik atau kurang sempurna, atau bisa juga terjadi karena bosan dengan kekasihnya saat ini. Hal ini dapat dilihat sebagai berikut.

Wes sayang tapi kunu kerjoane gk gena. Ono arek axar seng iso merhatikno aku. Yo mending pindah ae ws. Wkwk.

Sudah sayang tetapi dia kerjaannya tidak menentu. Ada orang baru yang bisa memerhatikan aku. Ya aku memilih pindah saja. Wkwk

Pada kutipan di atas menceritakan alasan sang perempuan memilih selingkuh, karena salah satunya yaitu memilih laki-laki yang mapan. Pada curahan tersebut tergambarkan bahwa sang perempuan sebenarnya telah memiliki kekasih. Tetapi karena kekasihnya tersebut tidak memiliki pekerjaan yang tetap, sehingga wanita lebih memilih lelaki yang baru, yang lebih memperhatikan, peduli dengan sang perempuan daripada tetap mempertahankan cintanya yang dahulu. Dari kutipan tersebut semakin memperjelas bahwa perempuan membutuhkan laki-laki yang mapan yang berani bertanggungjawab. Menurut perempuan hal yang demikian tidak dapat dipandang sebagai perempuan matre. Tetapi justru sebagai seorang laki-laki, ia harus memiliki tanggung jawab dan perhatian kepada perempuan salah satunya dengan memberikannya materi. Apabila kebutuhan materi perempuan (bedak, gincu, dll) terpenuhi maka seorang perempuan akan semakin menaruh rasa sayangnya kepada seorang laki-laki.

4 taun 7 wulan. Pedot kalahhh karo seng luweh nduwe. Ambyar kabeh. Sio ${ }^{2}$ pancen kerjo awan bengi.. Jancok teman.

4 tahun 7 bulan. Putus kalah dengan yang lebih punya. Ambyar semua. sia-sia sudah kerja siang bengi. Jancuk.

Menjalin sebuah ikatan rasa sayang hingga 4 tahun lamanya bukanlah waktu yang singkat bagi pasangan kekasih. Pasalnya dalam menjalin sebuah hubungan tentu pasti ada ombak badai yang menerjang dan mampu menghancurkan ikatan tersebut. Misalnya seperti pada 
komentar nitizen di atas yang mana rasa sayangnya selama empat tahun harus kandas lantaran kekasihnya memilih lelaki lain yang lebih nduwe. Nduwe di sini diartikan sebagai laki-laki yang memiliki segalanya salah satunya yaitu materi. Lelaki yang bekerja keras banting tulang dari siang sampai malam akan kalah dengan laki-laki yang mempunyai segalanya, terutama materi. Sebab seorang perempuan tentu tidak pernah menginginkan seluruh kebutuhannya tidak terpenuhi ataupun hidup sengsara. Terutama orangtua tentu tidak akan mengizinkan anaknya akan menikah dengan pria yang dapat dikatakan belum mapan atau belum memiliki penghasilan yang tetap, sebab mereka juga tidak ingin anaknya hidup sengsara. Maka ketika seorang perempuan yang bertemu dengan lelaki yang mau mencukupi kebutuhannya, tentu seorang perempuan tidak akan pernah menolaknya. Selain itu, sebagai seorang laki-laki sudah menjadi tanggungjawabnya untuk bekerja lebih giat agar dapat memberikan segala keinginan kekasihnya agar tetap bisa bahagia, serta rasa cintanya tetap terjaga.

Ajor pacaran 2 tahun dek e lebih milih pramugari ketimbang mlaku bareng karo aku seng wes ngancani wes nyukupi opo seng di karepi selama iki.

Hancur pacaran 2 tahun dia lebih memilih pramugari daripada jalan bersama dengan aku yang sudah menyukupi apa yang diinginkannya selama ini.

Bukan hanya perempuan yang selalu membuat lara di hati laki-laki, tetapi laki-laki terkadang juga membuat lara di hati perempuan seperti pada curahan hati di atas. Dalam Curahan hati seorang perempuan tersebut menceritakan bahwa ia pernah berjuang membahagiakan laki-laki yang dicintainya tetapi malah sang lelaki memilih pramugari dan meninggalkan keksihnya tersebut. Dalam curahan hati tersebut tergambar bentuk perjuangannya seperti menemani dan mencukupi segala keinginan yang diinginkan oleh sang lelaki, namun sayangnya sang lelaki tak pernah serius dalam menjalin hubungan dengan kekasihnya tersebut dan memilih berpaling dengan seorang pramugari. Dari curahan di atas dapat dikatakan bahwa seorang yang selingkuh juga dapat terjadi jika sepasang kekasih kurang menerima kekurangan dan kelebihan pasangannya. Seorang pramugari tentu memiliki paras cantik, sehingga laki-laki mana yang tidak mudah tertarik dengan perempuan cantik. Meskipun sang perempuan tersebut telah berjuang mempertaruhkan segalanya, tetapi sang lelaki tetap tidak ingin menerima kekurangan kekasihnya dan memilih berpaling darinya.

\section{Kangen}

Rasa kangen juga menjadi salah satu bagian dari fenomena ambyar di masyarakat. Hal ini terjadi ketika sepasang kekasih menjalin hubungan jarak jauh, sehingga ia merasa rindu dengan kekasihnya tersebut, atau biasa disebut sebagai LDR juga menahan rasa rindu dengan mantan kekasihnya karena dibenaknya masih menyimpan rasa cinta yang tulus untuknya. Fenomena yang demikian dapat dilihat dalam beberapa komentar netizen seperti berikut ini.

Kangen karo bojo ku.. Aku nang perantauan..bojoku nang kampung yg sedang mengandung anak pertamaku...LINTANG ATI KU JKT 30 JUNI 2019

Kangen dengan istriku.. aku di perantauan.. istriku di kampong yang sedang mengandung anak pertamaku...LINTANG ATI KU JKT 30 JUNI 2019 
Rasa kangen terhadap seseorang yang disayangi ternyata bisa membuat seseorang menjadi ambyar. Hal tersebut tentu akan terjadi pada pasangan yang menjalin hubungan LDR, atau jarang bertemu. Seperti dalam komentar nitizen di atas yang menggambarkan rasa rindunya kepada istri yang berada di kampong. Demi untuk bisa mencukupi kebutuhan sehari-hari, sang suami harus rela pergi merantau meninggalkan orang-orang yang disayangi seperti orangtua, istr ataupun anak. pergi jauh dengan keluarga tentu membuat hati seseorang ambyar, terlebih bagi suami-istri dan dalam keadaan istri mengandung. Tentu sebagai seoarngsuami ingin selalu berada di samping istri memanjakan istri dan memberikan perhatian lebih bagi si calon buah hati. Maka dari kutipan tersebut, sang suami merasa ambyar karena jauh dari orangorang yang disayanginya.

Rindu itu pasti ada. Tapi saya percaya dengan komitmen dia. Dan saya percaya bahwa suatu hari nanti dia pasti datang kembali dan saya sangat bersabar menunggu dia kembali:'v

Kutipan di atas juga dapat dikakan sebagai perasaan ambyar karena menahan rasa kangen dengan kekasihnya. Dalam kutipan tersebut menceritakan bahwa sang perempuan tengah menjalin hubungan jarak jauh dengan kekasihnya. Sang perempuan menejelaskan bahwa dia sedang menahan rasa rindu dengan kekasihnya. Tetapi sang perempuan percaya terhadap satu hal, yaitu komitmen, bahwa kekasihnya pasti akan datang kembali, sehingga snag perempuan pun bersabar menanti.

\section{Dadi Kangen banget karo Pacar ku (eh pacar mbuh mantan soale lungo tanpo pamitan)}

Jadi kangen dengan pacar ku (eh entah pacar atau mantan karena pergi tanpa pamitan)

Rasa rindu atau kangen, ternyata bukan hanya untuk pasangan suami istri atau pasangan yang sedang menjalin hubungan asmara jarak jauh. Tetapi rasa kangen juga sering melanda bagi orang-orang yang belum bisa move on dari mantan pacarnya. Misalnya seperti pada kutipan di atas yang menceritakan bahwa ia sedang menahan rindu dengan mantan pacarnya. Bisa dikatakan mantan pacar karena kekasihnya tersebut pergi tanpa kabar dan tanpa pamitan. rasa rindu tersebut dapat terjadi karena beberapa sebab. Misalnya karena memang benar-benar masih sayang dengan mantan kekasihnya, atau karena belum bisa melupakan semua kenangan-kenangan indah dengan kekasihnya. Tetapi jika dilihat, dalam kutipan tersebut menggambarkan rasa rindu dengan mantan kekasihnya karena dia masih menyimpan rasa sayang kepadanya.

\section{Ingat Kenangan}

Mengingat kenangan-kenangan indah bersama dengan sang kekasih ataupun mantan kekasih tentu akan emmbuat perasaan kita menjadi ambyar. Hal ini biasa terjadi karena dalamnya rasa cinta yang ia miliki untuk kekasihnya ataupun mantan kekasihnya, tetapi pada akhirnya harus dikhianati karena berbagai alasan. Beberapa fenomena yang ambyar karena ingat kenangan seperti berikut ini. 
Pacaran 3 thn susah sneng bareng. Putus 2012 mergo koe milih pakpol kae, mangan sego kucing, pas bolos sekolah, mangan steak nek dedet neng mun mun solo. Akhire koe saiki rabi ro pak polisi kae. Akhire aku yo rung move on 2012-2019.

Pacaran 3 tahun susah seneng bersama. putus 2012 karena kamu memilih pakpol (pak polisi) itu, makan nasi kucing, ketika bolo sekolah, makan steak jika punya uang di mun-mun solo. Akhirnya sekarang kamu menikah dengan pak polisi itu. Akhirnya aku belum bisa move on 2012-2019.

Curahan hati salah seorang nitizen yang ditemukan di jejaring social youtube pada 12 september 2019 ini menceritakan nasibnya yang sudah menjalani hubungan dengan kekasihnya selama 3 tahun namun pada tahun 2012, sang perempuan tersebut putus dan pergi meninggalkan sang pacarnya demi lelaki yang lebih mapan. Perempuan mana yang tidak tergoda apabila dilirik oleh seorang polisi yang tentu kehidupan kedepannya sudah terjamin. Tentu sang perempuan akan memilih laki-laki yang sudah mapan ini demi hidup yang bahagia. Namun terkadang sang perempuan tidak pernah melihat betapa sakit hatinya seorang laki-laki yang ditinggal pergi hanya karena dia belum mapan. Kenangan-kenangan indah selalu terkenang dan tidak akan terlupakan karena sang laki-laki begitu mencintai mantan kekasihnya tersebut. Begitulah yang tergambar dalam curahan hati tersebut. hal yang demikian tergambar dari curahan hati perempuan yang dapat dilihat sebagai berikut.

5 tahun pacaran eh mbok tinggal rabi nduk Surakarta,01 Oktober 2019

Loro atiku smp tembus tulang sumsum...gak bakal lali karo kelakuanmu, ****

bajingan

5 tahun pacaran eh sekarang kau tinggal menikah. Sakit hati ku sampai tembus

tulang sumsum.. nggak akan lupa dengan kelakuanmu, bajingan

Kutipan di atas dapat dikatakan sebagai bentuk penggambaran kenangan seseorang terhadap mantan kekasihnya. Dalam kutipan tersebut menggambarkan perasaan sakit yang diderita oleh seseorang karena merasa disakiti oleh mantan kekasihnya. Menjalin hubungan asmara selama 5 tahun berlalu, tetapi pada akhirnya ditinggal menikah oleh kekasihnya, pasti akan memunculkan rasa sakit hati dan kecewa. Hal tersebut berimbas pada amarah yang akhirnya ia tidak akan memaafkan perbuatan mantan kekasihnya tersebut.

Duh Garai kelingan mantan brondongq ae..esemane, lesung pipine, bodyne..

Pengendang jg. nyanyi seng ngendang kono, sing song wong 2, Aduch wezt gagal Move on kie q..

Duh membuat teringat mantan berondong ku saja. Senyumnya, lesung pipinya, bodynya.. tukang gendang juga. Nyanyi yang menggendangi dia, karaoke 2 orang. Aduh sudah gagal move aku ini.

Mendengar kisah Dori, yang ditinggal pergi oleh kekasihnya, ternyata juga pernah dialami oleh seseorang. hal ini terlihat seperti pada kutipan di atas. Dalam kutipan tersebut meceritakan bahwa dia tengah mengingat mantan kekasihnya yang masih muda, tampan, manis, macho dan juga seorang pemain gendang, semenjak melihat Dori. Kenangan yang 
tergambar dalam kutipan tersebut yaitu ketika mereka karaoke bareng, menyanyi dan mantan kekasihnya yang menggendangi. Kenangan tersebut teringat kembali ketika mendengar kisah Dori dan mendengar lagu kangen yang dibawakannya ketika berduet dengan Didi Kempot.

\section{Ingkar Janji}

Perasaan ingkar janji juga menjadi salah satu fenomena yang membuat perasaan menjadi ambyar. Beberapa fenomena di masyarakat menggambarkan bahwa ketika sepasang kekasih menjalin hubungan asrama, mereka sering berucap janji yang akhirnya dikhianati. Hal ini dapat dilihat dalam beberapa kutipan berikut.

3 tahun awak e dewe bareng,,ngalor ngidul ngetan ngulon... wong tuaku wes moro nang nggonтu karo adiku loro2ne, empet2an nang mobil soko solo tekan cilacap,,aku wes pasang cincin nang ngarep keluargamu,trus kowe ngerti2 lungo ngono wae,mergo masalah sepele...aku wes usaha esok sore kerjo,dingo pernikahane awak e dewe lebar wisudamu sesok oktober, lakok ngerti2 esok wes ra ono,,aku mbok tinggal nang ndi, iki wes ping 3 kowe minggatan,,sorry aku wes wegah goleki meneh,,matur suwun ngeh cah ayu,,mugi angsal ingkang luweh sae seko aku,,dongaku dingo awakmu,,, solo, 4 September 2019

Kekecewaan pada komentar nitizen di atas terlihat karena kekasihnya memilih pergi tanpa kabar. Kelakuan yang sudah berlangsung selama tiga kali tersebut jelas membuat sang lelaki kecewa karena mengingat perjuangannya demi untuk mempertemukan orangtuanya dengan orangtua kekasihnya tidak begitu mudah. Berada di mobil berhimpit-himpitan membawa keluarga dari solo ke cilacap dilakukan oleh sang lelaki demi sebuah ikatan, tetapi justru tidak mendapat respon yang positif karena kekasihnya yang sekarang ini memilih untuk pergi dan menghindar tanpa sebab alasan dan kabar. Kekecewaan ini timbul karena sang lelaki sudah bertukar cincin (tunangan) dengan kekasihnya, dan rela banting tulang pagi sampai sore demi setelah wisuda bulan Oktober, rencana mereka akan melangsungkan akad nikah harus kandas. Dengan melakukan tunaangan, berarti mereka telah berjanji akan melangkah ke jenjang pernikahan. Tetapi yang terjadi justru kekasihnya memilih pergi, sehingga kejadian tersebutpun membuat luka lara dihati sang lelaki dan sudah tidak ingin lagi menjalin ikatan dengan mantan kekasihnya tersebut.

Kisah saya pernah saya alami Kerja jauh2 nabung buat persiapan nikah Mau minta ortu yg gk mungkin... Balik ke Indonesia dan ternyata dapat kabar kalau org yg saya cinta $i$ sayang i mau menikah.. Dlu pernah janji akn menunggu sampai wkt yg pas... Akhr nya saiki ne CiDRO Klo dengar lagu ini saya pasti menentes kn air mata.. Percuma slama ini saya berjuang akhr nya cidro... Terima kasih mas Didi Kempot udh menciptakan lagu ini.... Semoga yg di sana sllu bhgia bersama nya...

Pada kutipan di atas seolah mewakili perasaan laki-laki yang ditujukkan kepada para perempuan, bahwa perjuangan yang dilakukan demi untuk membahagiakan perempuan tidaklah mudah. Misalnya pada kutipan di atas, seorang laki-laki yang menceritakan bahwa ia 
rela pergi jauh ke luar negeri, mencari uang dan menabung untuk persiapan menikah. Ia memiliki komitmen bahwa tentu ia tidak akan meminta uang pada kedua orangtuanya hanya untuk membahagiakan kekasihnya. Tetapi ketika ia kembali ke Indonesia, ternyata ia mendapat kabar bahwa kekasihnya telah menikah. Kecewa, sakit hati, itulah yang dirasakan oleh sang lelaki. Sang lelaki merasa dikhianati karena dulu mantan kekasihnya tersebut peernah berjanji bahwa ia akan menunggu sampai waktunya tiba, tetapi pada akhirnya harus diingkari dan membuat ambyar. Selain itu kutipan tersebut juga menggambarkan perasaan ambyar mengingat kenangan ketika mendengar lagu cidero. Sang laki-laki merasa bahwa lagu tersebut menggambarkan perasaannya yang merasa telah dikhianati atau diingkari janji.

Pacaran 3 thn nikah 9 juni bubar September SK munu tegone ninggalke aku ndi janjimu urep berbarengan ow masa ajurr sak ajurr2 ee

Pacaran 3 tahun nikah 9 juni bubar September segity teganya meninggalkan aku mana janjimu hidup berdampingan oh mas hatiku sangat hancur

Perasaan ambyar tidak hanya terjadi pada pasangan yang masih pacaran. Tetapi perasaan ambyar pada pengingkaran janji juga dapat terjadi pada pasangan suami istri seperti pada kutipan diatas. Kutipan komentar nitizen di atas juga menceritakan bentuk pengingkaran janji antara suami dan istri. Hal ini dapat dilihat dalam kutipan tersebut yang menceritakan bahwa suaminya sempat berjanji akan sehidup semati tetapi pada akhirnya, suaminya memilih untuk meninggalkan istrinya. Hal tersebut membuat sakit hati atau ambyar pada sang mantan istri dan menuliskan dalam salah satu komentar di video sebagai bentuk curahan isi hati.

\section{PENUTUP}

Sastra dan masyarakat memiliki hubungan yang saling bertalian. Karya sastra sebagai perwakilan kehidupan masyarakat mencoba untuk mendeskripsikan atau menggambarkan bentuk kehamilan masyarakat pada umumnya. Beberapa Lirik lagu campursari yang diciptakan dan dinyanyikan sendiri oleh Didi Kempot ini merupakan bentuk penggambaran rasa rindu, sakit hati dan kekecewaan dalam menjalin hubungan asrama dengan lawan jenis. Berdasarkan hasil uraian di atas, dapat disimpulkan bahwa lirik lagu Didi Kempot ini mewakili perasaan seseorang karena diselingkuhi, diingkari janji, kecewa, dan memendam rasa rindu. Penggambaran masyarakat tersebut dapat dilihat melalui komentar-komentar di status jejaring sosial. Beberapa yang melatarbelakangi fenomena ambyar ini dikarenakan kurangnya rasa perhatian atau komitmen dalam menjalin hubungan, factor ekonomi, menjalin hubungan jarak jauh, teringat kenagan-kenangan bersama mantan, dll.

\section{DAFTAR PUSTAKA}

Anonim. (2019). Pelajaran Berharga dari Lord Didi Kempot Bahwa Menangis Itu Sehat.

Retrieved January 10, 2019, from https://mojok.co/red/penjaskes/pelajaran-berharga-darilord-didi-kempot-bahwa-menangis-itu-sehat/

Antara. (2019). Identik dengan Lagu Patah hati; Didi Kempot pun Sebut Alasannya. Retrieved October 9, 2019, from https://beritagar.id/artikel-amp/laporan-khas/nelangsa-jiwa-dalam- 
tembang-jawa-ala-didi-kempot

Dwisantoso, A. (2019). Lord Didi Kempot, Pahlawan Kawula Ambyar. Retrieved September 19, 2019, from https://mojok.co/apd/corak/rerasan/lord-didi-kempot-pahlawan-kawulaambyar/

Marlina. (2018). Sosiologi Masyarakat Melayu Riau Dalam Syair "Surat Kapal” Karya H. Muhammad Ali Thalib (Sociology of Riau Melayu Community In The Poem "Ship Letter" by Muhammad Ali Thalib). Marlina, 6(2), 245-256.

Rahma, C., \& Wijaya, P. (2018). Cerminan Zaman dalam Puisi ( Tanpa Judul ) Karya Wiji Thukul : Kajian Sosiologi Sastra. Kembara, 4(1), 12-20.

Rizaldy, D. R. (2016). Aspek Sosial Budaya Masyarakat Jawa Dalam Novel Jalan Menikung: Para Priyayi 2 Karya Umar Kayam (Kajian Sosiologi Sastra). Media Prestasi, XVII(1), 26-40.

Suhardi. (2018). Nilai Budaya Minangkabau Dalam Cerpen “ Cimuntu Lansie ” Karya Wisran. Lingua Scientia, 10(1), 17-34.

Suharyo. (2018). Nasib Bahasa Jawa \& Bahasa Indonesia dalam Pandangan dan Sikap Bahasa Generasi Muda. NUSA, 13(2), 244-255.

Wahyuni, N. (2018). Kritik Sosial Dalam Teks Sastra Puisi Social Criticism In Literary Texts Of Poems. JURNAL ILMU PENDIDIKAN AHLUSSUNNAH, 1(2), 33-42.

Wiyoso, J. (2007). Jejak Campursari ( The History Of Campursari ). Harmonia Jurnal Pengetahuan Dan Femhoran Seni, 1(2), 108-116.

Yunianti, I. (2019). Denny Caknan dan Tren Baru Anak Muda Penyuka Campursari. Solopos, p. 9. 
Estetik, Vol.2 No.2, November2019

ISSN 2622-1810 (p) 2622-1829 (e) 